\title{
Plasma lipids and other cardiovascular risk factors in Costa Rican adolescents
}

\author{
Michael S. Irwig, ${ }^{1}$ Xinia Siles, ${ }^{2}$ Antonio M. Gotto, Jr., ${ }^{1}$ \\ Nader Rifai, ${ }^{3}$ and Hannia Campos ${ }^{2,4}$
}

\begin{abstract}
This study assessed plasma lipids and other cardiovascular risk factors in adolescents in a developing Latin American country and compared those risk factors to those of adolescents in the United States of America, where the risk of heart disease is high. In a cross-sectional study, data were collected from September 1998 to April 1999 on 161 Costa Rican adolescents between the ages of 12 and 20. A general questionnaire was used to collect demographic, smoking, socioeconomic, and women's health data. Anthropometric measurements, blood pressure, and a fasting blood sample were taken. The Costa Rican males had lower levels of total cholesterol than did the Costa Rican females (mean \pm standard error of the mean (SEM), $149 \pm 6.5$ $\mathrm{mg} / \mathrm{dL}$ vs. $158 \pm 6.3 \mathrm{mg} / \mathrm{dL}$ ). This was mainly due to lower high-density lipoprotein (HDL) cholesterol in males than in females (mean \pm SEM, $38 \pm 2.0 \mathrm{mg} / \mathrm{dL}$ vs. $44 \pm 2.4 \mathrm{mg} / \mathrm{dL}$ ). As compared to the United States, adolescents in this study had lower levels of total cholesterol, largely due to lower HDL cholesterol. Both genders of Costa Ricans had levels of low-density lipoprotein $(L D L)$ cholesterol that were similar to those of counterpart groups in the United States. Costa Rican male and female adolescents had higher LDL/HDL ratios than did their United States counterparts. Therefore, as compared to the United States, Costa Rican adolescents have an adverse lipid profile as demonstrated by a higher LDL/HDL ratio. Overweight prevalence in Costa Rica was 13\%, approaching the 15\% overall level of the United States.
\end{abstract}

In Costa Rica and many other developing countries throughout the world,

1 Cornell University, Department of Medicine, New York, New York, United States of America. Send correspondence to: Michael S. Irwig, M.D., 132 Turtle Creek Road, \# 3, Charlottesville, Virginia 22901, United States of America; telephone: 804295-7558; e-mail:msi5u@virginia.edu

2 Universidad de Costa Rica, Instituto de Investigaciones en Salud and Proyecto Salud Coronaria, San José, Costa Rica.

3 Children's Hospital of Boston, Department of Laboratory Medicine, Boston, Massachusetts, United States of America.

4 Harvard School of Public Health, Department of Nutrition, Boston, Massachusetts, United States of America. Send requests for reprints to: Hannia Campos, Department of Nutrition, Room 353, Harvard School of Public Health, 665 Huntington Ave., Boston, Massachusetts 02115, United States of America. the prevalence of infectious diseases has decreased while that of coronary heart disease (CHD) has increased (1). Many of the risk factors for CHD either begin or develop during adolescence and early adulthood. Serum lipoproteins and smoking have been closely related to the degree of atherosclerotic lesions in autopsied males aged 15-34 years (2). Adolescent overweight, even more so than adult overweight, is strongly correlated to morbidity and mortality from CHD (3). Many of the health patterns found during adolescence persist into adulthood and may become worse. For example, $70 \%$ of those with elevated cholesterol during youth continue to maintain high levels as young adults (4). Therefore, understanding adolescent health is essential for CHD prevention.

In our study we evaluated plasma lipids and other cardiovascular risk factors in adolescents in the San José, Costa Rica, metropolitan area. We compared the data collected from the Costa Rican subjects with recent nationally representative data from the United States of America (5). These comparisons are valuable to highlight the cross-cultural similarities and differences in CHD risk profile patterns. Understanding these risk factors will enable health care providers and educators to implement prevention strategies targeted at young people. 


\section{METHODS}

\section{Subject population}

This cross-sectional study consisted of 161 adolescents 12 to 20 years old whose parents or grandparents had been participants in a populationbased case-control study of myocardial infarction (MI) among adults in Costa Rica (6). We selected this methodology in order to yield a high participation rate because the research team had established regular contact and good rapport with the persons in the $\mathrm{MI}$ study. Of the 161 adolescents in our study, 80 of them were descendantseither children or grandchildren-of first-time MI survivors who were $\leq 75$ years old. Those MI survivors had been recruited from three San José-area public, social security hospitals between 1994 and 1998. The remaining 81 adolescents in our study were descendants of controls from our MI study. The MI controls had been randomly selected from the general population using census records and then matched with the MI cases by age, gender, and residence. Therefore, the adolescent descendants of this randomly selected control group were also a randomly representative population-based group.

We compared the groups of adolescents with and without a family history of MI to confirm that our selection criteria resulted in no statistically significant differences between the two groups, and we believe that the study population was fairly homogeneous.

Descendants of the MI control group were not necessarily free of a family history of MI, since other parents or grandparents might have been affected.

With the adolescents we used stratified random sampling to achieve a gender balance in the population. In order to make valid comparisons between groups in relation to anthropometric measurements and plasma concentrations, pregnant females were ineligible for the study.

To achieve equal family representation, only one descendant per adult could participate. In the case of multiple eligible children and/or grandchil- dren, one subject per family was chosen at random.

We telephoned MI study participants to inquire whether they had any eligible biological descendants who lived in metropolitan San José and who had a telephone in their home. Out of the 1062 participants in the adult study, 881 of them (83\%) had a telephone and lived in the metropolitan San José area. We placed 388 phone calls, and 325 of them (84\%) resulted in a successful contact with an MI study participant. Of those persons successfully contacted, 174 of them (53\%) had an eligible subject, that is, a child or grandchild who was between the ages of 12 and 20, lived in the San José metropolitan area, and had a telephone in the home. Out of those 174 eligible subjects, 161 (93\%) chose to participate in the study and were visited.

A medical student spoke to each of the eligible subjects and their parent(s) and explained that our study would entail an interview, various anthropometric measurements, a test of physical fitness (results not presented in this article), and a fasting blood sample. Potential subjects were also told that they would receive free blood tests for total cholesterol and glucose done by portable monitors, Spanish-language copies of Merck's guide to cholesterol and nutrition, and personalized certificates of appreciation that included the results of the measurements of blood, height, weight, blood pressure, and fitness. The medical student read aloud a written consent form for the adolescents to sign. For those adolescents under 18, an adult also signed.

The Human Subjects Committee of the Harvard School of Public Health approved the protocol for the study.

\section{Data collection}

We collected the data in San José, Costa Rica, from September 1998 through April 1999. We conducted 157 of the interviews (98\%) in the subjects' homes, with the remaining $4(2 \%)$ conducted at the project's downtown office. The mean interview length was $35 \mathrm{~min}$.
We used a general 10-minute questionnaire to collect demographic information, as well as data on physical activity, smoking, socioeconomic status, and women's health. The demographic information included age, sex, place of birth and of current residence (county and district within the San José metropolitan area), work/student status, and level of education completed. The smoking section asked whether they smoked regularly (an average of one or more cigarettes per day) and, if so, what quantity. Socioeconomic status was measured by the total score on an index of household electrical appliances, with common items (radio, television, refrigerator, etc.) assigned fewer points, and less common items (hot water tank, clothes dryer, computer, etc.) assigned more points. The women's health section inquired about age of menarche, having had a menstrual period within the preceding month, past pregnancies, and contraceptive use.

\section{Anthropometric measurements and blood pressure}

A trained medical student took anthropometric measurements, with subjects wearing light clothing as previously described (7). Height to the nearest $0.1 \mathrm{~cm}$ was measured with a steel anthropometer, with subjects standing upright, flat against a wall and on a hard-surface floor. Weight to the nearest $0.5 \mathrm{lb}$ was measured on a bathroom scale (seca Corporation, Hamburg, Germany). Body mass index (BMI) was calculated as weight $(\mathrm{kg}) /$ [height $(\mathrm{m})^{2}$ ]. The girth of the waist (smallest horizontal trunk circumference) and of the hip (largest horizontal trunk circumference, around the hip and buttocks) was measured with a nonstretching fiberglass tape. Duplicate waist and hip measurements were taken and then averaged for analysis. Three skinfold thicknesses were measured: triceps (posterior upper arm, halfway between the elbow and acromion), subscapular (1 cm inferior to the scapula's lower tip), and suprail- 
iac ( $2 \mathrm{~cm}$ superior to the anterior superior iliac spine). Each skinfold was measured on the left side of the body three times with Lange skinfold calipers (Beta Technology, Inc., Santa Cruz, California, United States). The BMI cut point used to identify those who were overweight was 25.3, which was the average of the United States 85th percentiles of BMI for 16-year-old males and 15-year-old females, 25.4 and 25.2, respectively (8). We used these ages from the United States since they were the same as the average ages of our male and female Costa Rican study participants.

Two fasting blood pressure measurements were obtained on the left arm of subjects in a relaxed, sitting position. The average of the two measurements was used in the analysis. A sphygmomanometer was used to record systolic and diastolic blood pressures at the first and fifth Korotkoff phases, respectively.

\section{Blood samples}

Blood samples were collected following the same procedures that we had used in two previous studies in Costa Rica $(7,9)$. All subjects were instructed to fast for $12-14 \mathrm{~h}$ before venipuncture. The last food intake was assessed by interview on the morning of the examination. One tube of blood was obtained in $0.1 \%$ EDTA. Immediately, a drop of blood was used for a glucose analysis by an Accu-Check II Blood Glucose Monitor with Chemstrip bG Test Strips (both, Roche Diagnostics, Indianapolis, Indiana, United States). Another drop of blood was used for a total cholesterol analysis done with a portable monitor and test strips (Roche Diagnostics, Indianapolis, Indiana, United States). Blood tubes were then stored in a cooler with ice packs at $4^{\circ} \mathrm{C}$. Within $4 \mathrm{~h}$ the specimens were centrifuged at $2500 \mathrm{rpm}$ for 20 $\min$ at $4^{\circ} \mathrm{C}$ to separate the plasma, buffy coat, and red cells. Plasma and buffy coat aliquots were then stored in a freezer at $-70{ }^{\circ} \mathrm{C}$ until they were transported with dry ice to the Har- vard School of Public Health in Boston, Massachusetts, United States, and subsequently to the Children's Hospital of Boston.

Plasma cholesterol and triglyceride concentrations were determined enzymatically on the Hitachi 911 analyzer (Roche Diagnostics, Indianapolis, Indiana, United States) at the Department of Laboratory Medicine at the Children's Hospital of Boston. The laboratory is certified by the Centers for Disease Control and Prevention (CDC) Lipid Standardization Program of the National Heart, Lung, and Blood Institute of the United States National Institutes of Health. The measurement of triglycerides was corrected for the presence of endogenous glycerol. The HDL cholesterol was determined by a homogeneous assay (HDL Plus, Roche Diagnostics) on the Hitachi 911 analyzer. Total cholesterol was determined with run-to-run coefficients of variation (CVs) of $1.8 \%$ and $1.5 \%$ at 128 and $267 \mathrm{mg} / \mathrm{dL}$, respectively; HDL-cholesterol CVs of $7.8 \%$ and $3.4 \%$ at 20.5 and $41 \mathrm{mg} / \mathrm{dL}$, respectively; and triglyceride CVs of $6.0 \%$ and $0.4 \%$ at 77 and $188 \mathrm{mg} / \mathrm{dL}$, respectively. LDL cholesterol levels were estimated for all subjects with triglyceride levels under $400 \mathrm{mg} / \mathrm{dL}$, using the Friedewald equation (10).

\section{Analyses}

We used Statistical Analysis System software (Cary, North Carolina, United States) for the data analyses. For the following variables, because of their skewed distributions, we used logarithmic transformations: weight, body mass index, waist, subscapular skinfold, suprailiac skinfold, total cholesterol, HDL cholesterol, LDL cholesterol, and triglycerides. Gender differences were assessed using two-tailed $t$ tests.

We compared data from the Costa Rican adolescents with data from the most recent nationally representative United States data, the Third National Health and Nutrition Examination Survey (NHANES III) (5). That United
States survey included males and females of all major ethnic/racial categories. For the United States subjects from ages 12 to 19 years, average plasma concentrations for total cholesterol and HDL cholesterol were calculated for 2920 subjects and for LDL cholesterol and triglycerides for 1095 subjects. The LDL cholesterol was calculated using the Friedewald formula (10). This study calculated the HDL and LDL cholesterols in the same manner as the NHANES III had. For the LDL/HDL ratio, however, our study calculated the ratios for each individual subject in Costa Rica. For the United States LDL/HDL ratio, we divided the mean population LDL cholesterol by the mean population HDL cholesterol. Therefore, our Costa Rica data for this ratio may be more precise.

\section{RESULTS}

\section{Males versus females}

Table 1 shows the general characteristics of the Costa Rican subjects by gender. Although both groups had completed a similar number of years of education, more of the females were then in school. There were only small differences in mean age, marital status, and socioeconomic status. Males were much more likely to be regular smokers $(16 \%$ vs. $1 \%, P=0.001)$.

The two groups differed markedly on a number of the anthropometric measurements. Males were taller, weighed more, and had larger waists and a higher waist-to-hip ratio $(P=$ 0.0001 for all). The body mass index was lower in females, but not significantly $(P=0.19)$. The prevalence of overweight was $15 \%$ in Costa Rican males and $11 \%$ in females. As compared to males, females had significantly higher fat deposition at the triceps $(P=0.0001)$ and suprailiac $(P=$ $0.04)$ areas. Males had significantly higher systolic blood pressure than did females $(P=0.0005)$.

In the 80 female subjects, 74 of them $(93 \%)$ had reached menarche by the time of the interview. Of those 74 
TABLE 1. Selected characteristics and cardiovascular risk factors for Costa Rican adolescents, by gender, 1998-1999a

\begin{tabular}{|c|c|c|c|}
\hline & $\begin{array}{l}\text { Males } \\
n=81\end{array}$ & $\begin{array}{c}\text { Females } \\
n=80\end{array}$ & $P$ value \\
\hline \multicolumn{4}{|l|}{ Basic variables } \\
\hline Participation rate $(\%)^{b}$ & 91 & 94 & \\
\hline Mean age (years) & $15.9(15.3,16.5)$ & $15.3(14.8,15.8)$ & 0.14 \\
\hline Marital status (\% single) & 99 & 99 & \\
\hline Menarche (years) & $n a^{c}$ & 12.2 & \\
\hline \multicolumn{4}{|l|}{ Education } \\
\hline Full-time students (\%) & 83 & 94 & \\
\hline Highest grade level completed & $8.4(7.8,9.0)$ & $8.2(7.7,8.7)$ & 0.69 \\
\hline \multicolumn{4}{|l|}{ Socioeconomic status } \\
\hline $\begin{array}{l}\text { Mean household electrical } \\
\text { appliance score }\end{array}$ & \multicolumn{2}{|c|}{ Mean household electrical } & 0.44 \\
\hline \multicolumn{4}{|l|}{ Smoking (\%) } \\
\hline Smoke regularly (avg > $1 \mathrm{cig} /$ day) & 16 & 1 & 0.001 \\
\hline \multicolumn{4}{|l|}{ Anthropometric measurements } \\
\hline Height $(\mathrm{cm})$ & $167.2(165.0,169.4)$ & $157.4(155.9,158.9)$ & 0.0001 \\
\hline Weight $(\mathrm{kg})$ & $60.2(56.7,63.7)$ & $51.6(49.3,53.9)$ & 0.0001 \\
\hline Body mass index $\left(\mathrm{kg} / \mathrm{m}^{2}\right)$ & $21.6(20.7,22.5)$ & $20.9(20.1,21.7)$ & 0.19 \\
\hline Obesity [BMI > 25.3] $(\%)^{d}$ & 15 & 11 & 0.50 \\
\hline Waist $(\mathrm{cm})$ & $74.1(71.8,76.4)$ & $67.3(65.6,69.0)$ & 0.0001 \\
\hline Hip (cm) & $90.5(88.3,92.7)$ & $88.7(86.8,90.7)$ & 0.23 \\
\hline Waist-to-hip ratio & $0.83(0.81,0.85)$ & $0.76(0.75,0.77)$ & 0.0001 \\
\hline \multicolumn{4}{|l|}{ Skinfolds } \\
\hline Triceps (mm) & $14.5(13.2,15.8)$ & $18.7(17.4,20.0)$ & 0.0001 \\
\hline Subscapular (mm) & $14.3(12.6,16.0)$ & $15.7(14.0,17.4)$ & 0.19 \\
\hline Suprailiac $(\mathrm{mm})$ & $11.1(9.6,12.6)$ & $13.7(12.2,15.2)$ & 0.04 \\
\hline Blood pressure & $n=74$ & $n=77$ & \\
\hline Mean systolic BP (mm Hg) & $112.7(109.9,115.5)$ & $106.5(104.5,108.5)$ & 0.0005 \\
\hline Mean diastolic BP $(\mathrm{mm} \mathrm{Hg})$ & $67.8(65.6,70.0)$ & $66.6(64.9,68.3)$ & 0.41 \\
\hline
\end{tabular}

young women, 70 of them had had a menstrual period within the preceding month. Two of the women had been pregnant before the time of the interview, and six of them had taken oral contraceptives for birth control or menstrual regulation sometime during adolescence.

\section{Lipids in Costa Rica versus the United States}

Table 2 depicts the lipid profiles for the Costa Rican adolescents, along with previously published data for their United States counterparts (5). The plasma lipids show wide variation by both gender and nationality. Within the Costa Rican population, the total cholesterol is somewhat higher for fe- males than males. For both genders of Costa Rican adolescents, total cholesterol was lower in the older group (16-20 years old) than in the younger group (12-15 years old). For females, this difference is primarily due to lower HDL cholesterol levels among older females. For males, the lower total cholesterol represents lower levels of both HDL and LDL cholesterol, as is also shown by the LDL/HDL ratios, which are the same for both age groups of males. According to cut points established by the National Cholesterol Education Program of the United States (11), the proportions of Costa Rican males and females with borderlinehigh or high cholesterol were similar (23\% vs. $26 \%$ ), with borderline-high and high cholesterol being 170-199 $\mathrm{mg} / \mathrm{dL}$ and > $200 \mathrm{mg} / \mathrm{dL}$, respectively.
The concentration of total cholesterol of $170 \mathrm{mg} / \mathrm{dL}$ most closely corresponds to the 75th percentile for adolescents in the United States.

As compared to adolescents in the United States, Costa Ricans had somewhat lower levels of total cholesterol. This lower level reflected lower HDL cholesterol for all the Costa Rica age/ sex groups, along with LDL levels that were similar to those in the United States. Therefore, all the Costa Rican groups had higher LDL/HDL ratios than did the United States groups.

The mean triglyceride levels were higher among older Costa Rican males than they were among younger males; the reverse was true for the younger and older Costa Rican females. Nevertheless, the standard errors for the mean triglyceride levels were rather 
TABLE 2. Plasma lipid profile of male and female adolescents in Costa Rica and in the United States of Americaabc

\begin{tabular}{|c|c|c|c|c|}
\hline & \multicolumn{2}{|c|}{ Males } & \multicolumn{2}{|c|}{ Females } \\
\hline & Costa Rica & United States & Costa Rica & United States \\
\hline \multicolumn{5}{|c|}{ Total cholesterol (mg/dL) } \\
\hline all & $149(6.5)$ & $158(1.2)$ & $158(6.3)$ & $167(1.3)$ \\
\hline younger & $153(9.4)$ & $158(1.6)$ & $162(7.9)$ & $164(1.9)$ \\
\hline older & $146(9.0)$ & $158(1.8)$ & $153(10.2)$ & $171(2.3)$ \\
\hline \multicolumn{5}{|c|}{ HDL cholesterol $(\mathrm{mg} / \mathrm{dL})^{\mathrm{d}}$} \\
\hline all & $38(2.0)$ & $47(0.6)$ & $44(2.4)$ & $52(0.5)$ \\
\hline younger & 40 (3.2) & $48(0.7)$ & $46(3.4)$ & $51(0.8)$ \\
\hline older & $36(2.3)$ & $46(0.9)$ & $42(3.3)$ & $52(0.7)$ \\
\hline \multicolumn{5}{|c|}{ LDL cholesterol (mg/dL)e } \\
\hline all & $92(5.7)$ & $91(2.1)$ & $95(5.4)$ & $99(2.4)$ \\
\hline younger & $95(8.1)$ & $88(2.4)$ & $96(6.3)$ & $94(2.8)$ \\
\hline older & $89(7.9)$ & $94(3.8)$ & $94(9.5)$ & $103(4.4)$ \\
\hline \multicolumn{5}{|c|}{ Triglycerides } \\
\hline all & $78(11.0)$ & $91(4.0)$ & $78(9.1)$ & $96(3.9)$ \\
\hline younger & $69(13.9)$ & $87(7.0)$ & $84(13.4)$ & $96(5.6)$ \\
\hline older & $87(16.4)$ & $94(6.1)$ & 70 (10.3) & $96(5.9)$ \\
\hline \multicolumn{5}{|c|}{ LDL/HDL ratio ${ }^{f}$} \\
\hline all & 2.6 & 1.9 & 2.3 & 1.9 \\
\hline younger & 2.6 & 1.8 & 2.2 & 1.8 \\
\hline older & 2.6 & 2.0 & 2.4 & 2.0 \\
\hline \multicolumn{5}{|c|}{ Total cholesterol > $170(\%)^{g}$} \\
\hline all & 23 & nah & 26 & na \\
\hline younger & 23 & na & 30 & na \\
\hline older & 24 & na & 21 & na \\
\hline \multicolumn{5}{|c|}{$\begin{array}{l}\text { Data for Costa Rican adolescents are from our study, 1998-1999 (data are from } 80 \text { males and } 79 \text { females); data for United } \\
\text { States adolescents are from the Third National Health and Nutrition Examination Survey, 1988-1994 (5). } \\
\text { b Plasma values are given as the mean in mg/dL, with the standard error of the mean in parentheses. } \\
\text { c Younger = 12-15 years old in both countries; older = 16-20 years old for Costa Rica and 16-19 years old for the United } \\
\text { States. } \\
\text { d HDL = high-density lipoprotein. } \\
\text { e LDL = low-density lipoprotein. } \\
\text { For the United States, the LDL/HDL ratio was calculated as the mean LDL/mean HDL. } \\
\text { g Total cholesterol was as defined by the National Cholesterol Education Program, } 1992 \text { (11). The concentration of total cho- } \\
\text { lesterol of } 170 \mathrm{mg} / \mathrm{dL} \text { most closely corresponded to the } 75 \text { th percentile for adolescents in the United States. } \\
\text { na = not available. }\end{array}$} \\
\hline
\end{tabular}

large, due to the small numbers of persons in the various subgroupings of the Costa Rican adolescents. As compared to their United States counterparts, Costa Rican females had lower plasma triglycerides.

\section{DISCUSSION}

\section{Plasma lipids}

The average total cholesterol in Costa Rican adolescents was $154 \mathrm{mg} / \mathrm{dL}$, which is low compared to many Western countries, including the United States (163 mg/dL). However, this finding among Costa Ricans was due to lower HDL cholesterol levels but similar LDL levels. As compared to the rise in total cholesterol concentrations (13). Worldwide, the differences in total cholesterol according to ethnicity that are seen in both genders in childhood and adolescence become much smaller by age 19 (14). The Bogalusa Heart Study of white and black children in the state of Louisiana in the United States found that the serum lipoprotein changes that occurred during sexual maturation varied depending on gender and race (4). Among all the groups in that study, total, $\mathrm{HDL}$, and LDL cholesterol declined during puberty. At maturation, the white male group showed a marked decline in HDL and an increase in LDL.

The Costa Rican adolescents we studied were predominantly white, with varying degrees of indigenous heritage. One would thus expect that the trends among them would parallel those that the Bogalusa investigators found among white adolescents in Louisiana. Nevertheless, we found similar lipid levels for both the younger and older Costa Rican adolescents. Rather than reflecting actual differences, the trends we observed in Costa Rica may have been due to the small sample sizes. The LDL cholesterol in United States adolescents is higher in the older group than in the younger one, especially for females. In all the age and sex groupings, the Costa $\mathrm{Ri}$ cans had lower HDL cholesterol levels than did their United States counterparts. We found similar patterns when we studied adults in Costa Rica and compared them to the adults in the United States in the Framingham Heart Study (9).

It is possible that these differences among populations, ages, and genders are mediated by interactions between genetic effects and such environmental factors as diet. For example, Costa Ricans have diets higher in carbohydrates than do persons in the United States (9), and increased carbohydrates lower HDL cholesterol (15). In males, a decrease in HDL cholesterol during adolescence can be partly explained by an increase in testosterone production (16).

As compared to their counterparts in the United States, the lower levels of 
total cholesterol for both age groups and genders of the adolescent Costa Ricans we studied are misleading. By our using the borderline-high total cholesterol cut point for the Costa Rican adolescents, we mask some of the risk they face. That is because it is the lower HDL cholesterol that accounts for the lower total cholesterol. The LDL/HDL ratios, on the other hand, show that Costa Ricans have higher ratios in both males and females (2.6 and 2.3) as compared to their United States counterparts (1.9 and 1.9). The LDL/HDL ratio is the variable that most clearly would predict the increased CHD risk for Costa Rican adolescents (17). Thus, our data suggest that adolescents in Costa Rica may be at increased risk of CHD as compared to adolescents in the United States. This situation in Costa Rica is worrisome since it may indicate a trend toward further future increases in CHD in developing countries.

Costa Rican adolescents show patterns of plasma triglycerides similar to those in other countries (14). For males, triglycerides tend to be higher among older adolescents. For females, however, triglycerides are lower among the older group. High triglyceride levels are an independent predictor for heart disease (18). It is interesting to note that Costa Rican adolescent females have lower triglycerides than do United States adolescent females. These findings differ from ones previously reported for Costa Rican adults, who had higher triglycerides levels than adults in the United States (9). The reasons for this pattern are unclear.

\section{Anthropometric measurements}

Overweight has become an increasingly common risk factor in modern times. Both adolescents and adults are leading more sedentary lives and exercising less. Obesity among the Louisiana adolescents in the Bogalusa Heart Study has increased over the past few decades, and between 52\% and $62 \%$ of the persons who had been overweight as adolescents were also overweight 14 years later (19). With similar total energy intake the average 10-year-old in the Bogalusa research was $3 \mathrm{lb}(1.4 \mathrm{~kg})$ heavier in 1988 than in 1973 (20).

In Costa Rica the average BMI for adolescents was very similar to that in the United States (21). Surprisingly, as compared to the United States, an equal percentage of Costa Rican males $(15 \%)$ were overweight. One would expect that overweight prevalence would be less in a developing country, where there may be greater levels of malnutrition and less of the sedentary activity associated with televisions and computers. For Costa Rican females, $11 \%$ were defined as overweight, as compared to $15 \%$ in the United States.

Using mean values, Costa Rican adolescent males in our study were very similar in height to United States males. Surprisingly, however, the Costa Rican females were about $4 \mathrm{~cm}$ shorter than their United States counterparts. The Costa Rican males weighed on average $4 \mathrm{~kg}$ less than United States males. The Costa Rican females weighed on average $5 \mathrm{~kg}$ less than United States females (22). These gender differences in relative height suggest cultural gender discrepancies in protein and other nutrient intake during childhood.

Our most intriguing anthropometric data were the skinfold measurements, where we found that the Costa Rican adolescents had more fat deposition than counterparts in Great Britain and in Australia. In comparison to British adolescents measured in 1966 (23), the Costa Rican adolescents we studied had much more fat deposition. At the triceps, the 50th percentiles for British males 12 and 19 years old were $9 \mathrm{~mm}$ and $10 \mathrm{~mm}$, respectively. The mean triceps measurement for the Costa Rican males was $14.5 \mathrm{~mm}$. The 50th percentiles for British females 12 and 19 years old were $12 \mathrm{~mm}$ and $16 \mathrm{~mm}$, respectively. The mean triceps measurement for the Costa Rican females was $18.7 \mathrm{~mm}$. The subscapular skinfold data for the Costa Ricans yielded the same pattern of larger measurements than were found with their British counterparts. In an Australian study (24), the mean triceps and subscapular skinfolds for males were $9.4 \mathrm{~mm}$ and
$10.5 \mathrm{~mm}$, respectively. For females, the corresponding measurements were $16.5 \mathrm{~mm}$ and $13.7 \mathrm{~mm}$. Possible explanations for the large differences between the mean values found in the various countries may include different measurement techniques used by the researchers, genetic differences among the populations, and an increasing trend towards obesity over the last few decades.

\section{Smoking}

Worldwide, smoking prevalence varies greatly depending on multiple factors, including age, gender, culture, and educational level. Our data on the Costa Rican adolescents found smoking prevalence rates of $16 \%$ among males and $1 \%$ among females. The overall prevalence rate, $9 \%$, was similar to the one found in a previous study of Costa Rican high school students (25). That earlier study found smoking rates of $5 \%$ in students 13 to 15 years old, $12 \%$ in those 16 to 18 years old, and $20 \%$ in those 19 years or older. These rates are lower than ones found in some other Latin American countries, such as the $57 \%$ for persons 15 to 19 years old in Peru and the $41 \%$ for that same age group in Cuba (26).

\section{Blood pressure}

Blood pressure is another $\mathrm{CHD}$ risk factor that varies according to age, gender, and country. Among the Costa Rican adolescents we studied, there was little gender difference in diastolic blood pressure, but males had an average systolic blood pressure that was 6 $\mathrm{mm} \mathrm{Hg}$ higher. Rosner et al. (22) have compiled blood pressure nomograms for United States adolescents based on the combined data from nine large studies. As compared to these United States values, the diastolic blood pressure in Costa Rican males and females was 5-6 $\mathrm{mm} \mathrm{Hg}$ higher. Males in Costa Rica and the United States had similar systolic blood pressure values, as also did the females. An Australian study of 18-yearolds found similar trends among the 
genders (24). As compared to the Australian females, the Australian males had a slightly higher mean diastolic pressure (65.4 vs. 63.7) but a noticeably higher systolic pressure (126.7 vs. 112.9).

\section{General comments and conclusion}

This study examined plasma lipids and other cardiovascular risk factors for an adolescent population in Costa Rica and compared this population with a nationally representative United States population studied recently in the Third National Health and Nutrition Examination Survey (5). Both studies measured lipids in laboratories that had been certified by the CDC Lipid Standardization Program. In addition, both studies calculated the LDL cholesterol in the same manner.

Our study had several potential limitations that should be considered. First, our study excluded the lowest socioeconomic segment of Costa Rican soci- ety by requiring that study participants have a telephone in the home; $78 \%$ of Costa Ricans do have a telephone in the home (our unpublished data). Second, our population of Costa Rican adolescents was not truly representative of all Costa Rican adolescents, due to a family history of MI in half of our subjects. Within our study population we found no statistically significant differences based upon family history of MI, but that may have been due in part to our relatively small sample size. And, we believe that there was less bias with our population than if we had used a school- or university-based sample, which would have been skewed towards the higher socioeconomic strata of Costa Rican adolescents.

Many Costa Rican adolescents in this study had a worrisome cardiovascular risk profile already established. As compared to their United States counterparts, the Costa Ricans had lower total cholesterol levels but could face an increased CHD risk because of their higher LDL/HDL ratios. Also indicative of these troubling health trends was the prevalence of overweight and smoking that we found among the Costa Ricans. Given this situation in Costa Rica, health care providers and educators there should focus additional health promotion and risk prevention efforts on young people.

Acknowledgments. The authors would like to thank all of the participants and their parents and/or grandparents. In addition, we extend great appreciation to Carlos Hidalgo for transportation to the subjects' homes, and to José Marín Siles and Sucharita Sen for their computer assistance and knowledge. The project was supported by an American Heart Association Medical Research Fellowship provided through Cornell University Medical College, and by research grant HL 49086 from the National Institutes of Health of the United States.

\section{REFERENCES}

1. Pan American Health Organization: Health conditions in the Americas, 1994 edition. Washington, D.C.: PAHO; 1994. (Scientific Publication No. 549).

2. Pathobiological Determinants of Atherosclerosis in Youth (PDAY) Research Group. Relationship of atherosclerosis in young men to serum lipoprotein cholesterol concentrations and smoking. JAMA 1990;264:3018-3024.

3. Hoffmans MDAF, Kromhout D, DeLezenne Coulander $\mathrm{C}$. The impact of body mass index of 78,612 18-year-old Dutch men on 32-year mortality from all causes. J Clin Epidemiol 1988;41:749-756.

4. Srinivasan SR, Berenson GS. Childhood lipoprotein profiles and implications for adult coronary artery disease: the Bogalusa Heart Study. Am J Med Sci 1995;310(suppl 1):S62S67.

5. Hickman TB, Briefel RR, Carroll MD, Rifkind BM, Cleeman JI, Maurer KR, et al. Distributions and trends of serum lipid levels among United States children and adolescents ages 4-19 years: data from the Third National Health and Nutrition Examination Survey. Prev Med 1998;27:879-890.

6. Campos H, Siles X. Siesta and the risk of coronary heart disease-results from a population-based, case-control study in Costa Rica. Int J Epidemiol 2000;29(3):429-437.
7. Campos H, Bailey SM, Gussak LS, Siles X, Ordovas JM, Schaefer EJ. Relations of body habitus, fitness level, and cardiovascular risk factors including lipoproteins and apolipoproteins in a rural and urban Costa Rican population. Arteriosclerosis Thromb 1991;11: 1077-1088.

8. Rosner B, Prineas R, Loggie J, Daniels SR. Percentiles for body mass index in U.S. children 5 to 17 years of age. J Pediatr 1998;132: 211-222

9. Campos H, Willett WC, Peterson RM, Siles X, Bailey SM, Wilson PW, et al. Nutrient intake comparisons between Framingham and rural and urban Puriscal, Costa Rica. Arteriosclerosis 1991;11:1089-1099.

10. Friedewald WT, Levy RI, Fredrickson DS. Estimation of the concentration of low-density lipoprotein cholesterol in plasma, without use of the preparative ultracentrifuge. Clin Chem 1972;18:499-502.

11. American Academy of Pediatrics. National Cholesterol Education Program: report of the expert panel on blood cholesterol levels in children and adolescents. Pediatrics 1992;89(3 Pt 2):525-584.

12. Wynder EL, Williams CL, Laakso K, Levenstein M. Screening for risk factors for chronic disease in children from fifteen countries. Prev Med 1981;10:121-132.
13. Labarthe DR, O'Brien B, Dunn K. International comparisons of plasma cholesterol and lipoproteins. Ann NY Acad Sci 1991;623: 108-119.

14. Brotons C, Ribera A, Perich RM, Abrodos D, Magana P, Pablo S, et al. Worldwide distribution of blood lipids and lipoproteins in childhood and adolescence: a review study. Atherosclerosis 1998;139(1):1-9.

15. Mensink RP, Katan MB. Effect of dietary fatty acids on serum lipids and lipoproteins. Arteriosclerosis Thromb 1992;12:911-919.

16. Solyom A. Effects of androgens on serum lipids and lipoproteins. Lipids 1972;7:100-105.

17. Stampfer MJ, Sacks FM, Salvini S, Willett WC, Hennekens $\mathrm{CH}$. A prospective study of cholesterol, apoproteins, and the risk of myocardial infarction. N Engl J Med 1991;325: 373-381.

18. Austin MA, Hokanson JE, Edwards KL. Hypertriglyceridemia as a cardiovascular risk factor. Am J Cardiol 1998;81:7B-12B.

19. Srinivasan SR, Bao W, Wattigney WA, Berenson GS. Adolescent overweight is associated with adult overweight and related multiple cardiovascular risk factors: the Bogalusa Heart Study. Metabolism 1996;45:235-240.

20. Nicklas TA. Dietary studies of children: the Bogalusa Heart Study experience. J Am Diet Assoc 1995;95:1127-1133. 
21. United States, National Center for Health Statistics. Anthropometric reference data and prevalence of overweight, 1987. Hyattsville, Maryland, United States of America: National Center for Health Statistics; 1987. (DHHS Publication No. (PHS) 87-1688; Vital statistics report from the National Health Survey, series 11 , no. 238).

22. Rosner B, Prineas RJ, Loggie JM, Daniels SR. Blood pressure nomograms for children and adolescents, by height, sex, and age, in the United States. J Pediatr 1993;123(6):871-886.

23. Tanner JM, Whitehouse RH. Revised standards for triceps and subscapular skinfolds in
British children. Arch Dis Childhood 1975;50: 142-145.

24. Milligan R, Burke V, Dunbar DL, Spencer M, Balde E, Beilin LJ, et al. Associations between lifestyle and cardiovascular risk factors in 18-year-old Australians. J Adolesc Health 1997; 21:186-195.

25. Muestra de estudiantes de secundaria del área metropolitana. Clínica de atención integral a la adolescencia. Situación actual de la adolescencia en la educación secundaria en Costa Rica y alternativas hacia una salud integral. San José, Costa Rica: Organización Panamericana de la Salud; 1991.
26. Pan American Health Organization. Health in the Americas, 1998 edition. Washington, D.C.: PAHO; 1998. (Scientific Publication No. 569).

Manuscript received on 13 October 1999. Revised version accepted for publication on 8 June 2000.

RESUMEN En este estudio se investigaron los lípidos plasmáticos y otros factores de riesgo cardiovascular en adolescentes de un país latinoamericano en desarrollo y se compararon con los factores de riesgo de los adolescentes de los Estados Unidos de América Lípidos plasmáticos y otros
factores de riesgo
cardiovascular en (EUA), en los que el riesgo de cardiopatía es alto. El estudio, de tipo transversal, se realizó entre septiembre de 1998 y abril de 1999, y recogió datos de 161 adolescentes costarricences de 12 a 20 años de edad. Mediante un cuestionario general se registró la información demográfica, socioeconómica, obstétrico-ginecológica y sobre el consumo de tabaco. Se efectuaron mediciones antropométricas, se registró la tensión arterial y se obtuvieron muestras de sangre en ayunas. Los varones costarricenses tenían concentraciones totales de colesterol inferiores a las de las mujeres costarricenses (media \pm error estándar de la media (EEM) $149 \pm 6,5 \mathrm{mg} / \mathrm{dL}$ frente a $158 \pm$ $6,3 \mathrm{mg} / \mathrm{dL}$ ). Esto se debió, sobre todo, a las menores concentraciones de colesterol de las lipoproteínas de alta densidad (HDL) en los hombres que en las mujeres (media \pm $\mathrm{EEM}, 38 \pm 2,0 \mathrm{mg} / \mathrm{dL}$ frente a $44 \pm 2,4 \mathrm{mg} / \mathrm{dL}$ ). En comparación con los adolescentes de los EUA, los de Costa Rica tenían menores niveles de colesterol total, debido sobre todo al colesterol de las HDL. Los costarricenses de ambos sexos tenían concentraciones de colesterol de las lipoproteínas de baja densidad (LDL) similares a las de los grupos correspondientes en los EUA y mayores razones LDL/HDL. Por tanto, en comparación con los adolescentes de los EUA, los costarricenses tenían un perfil lipídico adverso, como demuestra la mayor razón LDL/HDL. La prevalencia del sobrepeso en Costa Rica fue del 13\%, cercana al 15\% global de los EUA. 